\title{
Experimental Study On The Properties Of Concrete With Partial Replacement Of Sand By Plastic Pet Bottle Fiber
}

\author{
Sudip Joshi, Nawraj Bhattarai
}

\begin{abstract}
The use of plastic is increasing day by day, although steps were taken to reduce its consumption. The suitability of replacement of plastic pet bottle fiber as sand in concrete and its advantages are studied here. Plastic bottles are a major issue of solid waste disposal. Several things which were invented for our convenient life are responsible for polluting environment due to improper waste management technique. Polyethylene Terephthalate (PET) is used for carbonated beverage and water bottles. This is an environmental issue as waste plastic bottles are difficult to biodegrade and involve processes either to recycle or reuse. In the Modern world, the construction industry is searching for cost-effective materials for enhancing the strength of concrete structures. This study is carried out with the possibility of using the waste PET bottles as the partial replacement of fine aggregate in Ordinary Portland cement. The percentage substitution that gives higher compressive strength was used for determining the other properties such as flexural strength test.
\end{abstract}

Index Terms - Concrete, Cement, Fine aggregates, Coarse aggregates, Plastic pet bottle fiber

\section{INTRODUCTION}

During the resent years, awareness is increased regarding environmental pollution due to domestic and industrial waste. When once environment is allowed to degrade, it will take huge amount of public exchequers to clean it so in view of this, it is better to prevent than searching of solution for concrete. Concrete is in general, cement based, which meets special performance requirement with regards to workability, strength and durability, that cannot always be obtained with techniques and materials adopted for producing convention cement concrete. Fine aggregate is important construction materials, which is widely used in construction works.

Concrete is widely used materials in the world. Based on global uses it is placed at second position after water. River sand is one of the constituents used in the production of the concrete has become highly expensive and also scare. In the backdrop of such a bleak atmosphere, there is large demand for alternative materials from the industrial and household waste. Similarly the waste plastic pet bottle can be used as the alternative materials for the partial replacement of the sand.

\subsection{Main Objectives}

Sudip Joshi, Department of Mechanical Engineering , Trivhuban University/ Pulchowk Campus/ Pulchowk, Lalitpur Nepal, Phone +0977-9841495468

Nawraj Bhattarai, (Department of Mechanical Engineering, Tribhuvan University/ Pulchowk Campus/ Pulchowk, Lalitpur Nepal,)
The main objective of this study is to evaluate the possibility of using plastic pet bottle fiber as partial replacement of fine aggregate (sand) in concrete.

Specific objectives of this work include:

1) To determine the properties of plastic fiber.

2) To conduct a comparative study of plastic pet fiber and sand.

3) To study the effect of replacing sand with plastic pet bottle fiber on compressive strength and flexural strength of concrete.

4) To study the effect of replacing sand with plastic pet fiber on weight of concrete.

5) To find the optimum percentage of replacement of sand using plastic pet fiber.

\section{METHODOLOGY}

The whole research was based on laboratory experiment so the approach of the research adopted here was Experimental Research. The following flow chart illustrates the methodology of the study.

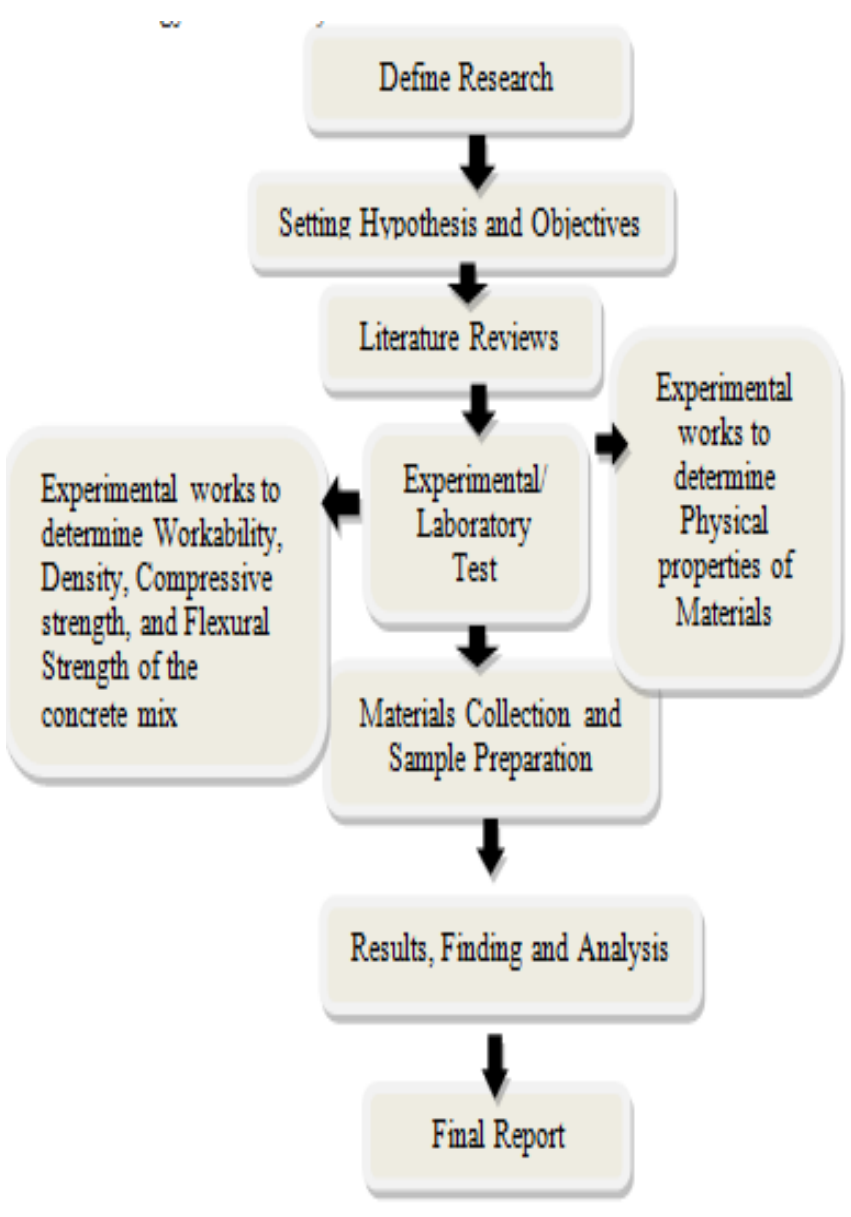


Figure 1: Flow Chart of Methodology

\subsection{Material Used}

\begin{tabular}{|l|l|}
\hline Basic material & \multicolumn{1}{c|}{ Specifications } \\
\hline Cement & $\begin{array}{l}\text { Ordinary Portland cement Of 53 Grade from } \\
\text { Maruti Cement was used. }\end{array}$ \\
\hline Sand & $\begin{array}{l}\text { The fine aggregate was sand from River Sand } \\
\text { Belkhu having a specific gravity 2.632. }\end{array}$ \\
\hline Gravel & $\begin{array}{l}\text { Maximum size of 20 mm, specific gravity of } \\
\text { 2.694 was used as coarse aggregate. }\end{array}$ \\
\hline Plastic Pet Bottles & $\begin{array}{l}\text { Recycled waste plastic PET Bottles with a } \\
\text { percentage 1\%, 2\%, 2.5\%, 3\% and 5\% } \\
\text { replacement of sand was used. }\end{array}$ \\
\hline Water & $\begin{array}{l}\text { Fresh water was used for mixing process and } \\
\text { curing. }\end{array}$ \\
\hline
\end{tabular}

In this study, $1 \%, 2 \%, 2.5 \%, 3 \%$ and $5 \%$ of sand were replacement of plastic pet bottle fiber in M20 grade concrete. The replacement percentage is by weight of total sand content derived from the mix proportion. Cube specimens of size $150 \times 150 \times 150 \mathrm{~mm}$, and beam specimens of size $75 \mathrm{~mm} \times 75$ $\mathrm{mm} \times 300 \mathrm{~mm}$. Various Specimen types prepared are listed in Table 2

Table 2:.Various specimen type prepared

\begin{tabular}{|c|c|c|c|c|c|c|c|c|}
\hline \multirow{2}{*}{$\begin{array}{l}\mathrm{S} \\
\mathrm{N}\end{array}$} & \multirow{2}{*}{$\begin{array}{l}\text { Specimen } \\
\text { Type }\end{array}$} & \multicolumn{6}{|c|}{ No of specimen Prepared } & \multirow{2}{*}{$\begin{array}{r}\text { Total } \\
\text { specimen }\end{array}$} \\
\hline & & $0 \%$ & $1 \%$ & $2 \%$ & $2.5 \%$ & $3 \%$ & $5 \%$ & \\
\hline 1 & Cube & 4 & 4 & 4 & 4 & 4 & 4 & 24 \\
\hline 2 & Beam & 4 & 4 & 4 & 4 & 4 & 4 & 24 \\
\hline & \multicolumn{7}{|c|}{ Total no of specimen prepared } & 48 \\
\hline
\end{tabular}

Considering the M20 grade of concrete with water cement ratio as 0.50 , the concrete mix was designed according to IS 10262:2009. Concrete without the mix of Plastic pet bottles fibers was used as the control sample. The different proportions of cement, sand, aggregate, plastic fiber and water were determined.

Table 3: Design values of mixes according to Indian Standard Guidelines.

\begin{tabular}{|l|l|l|l|l|l|l|}
\hline \multirow{2}{*}{ Particulars } & \multicolumn{6}{|c|}{ Design Values for the different percentage of Plastic } \\
\cline { 2 - 7 } & $0 \%$ bottle fibers & $1 \%$ & $2 \%$ & $2.5 \%$ & $3 \%$ & $5 \%$ \\
\hline $\begin{array}{l}\text { Concrete } \\
\text { grade }\end{array}$ & M20 & M20 & M20 & M20 & M20 & M20 \\
\hline $\begin{array}{l}\text { Characteristi } \\
\text { c Strength } \\
\text { (MPa) }\end{array}$ & 20 & 20 & 20 & 20 & 20 & 20 \\
\hline $\begin{array}{l}\text { Target } \\
\text { Compressiv } \\
\text { e Strength } \\
\text { (MPa) }\end{array}$ & 25.94 & 25.94 & 25.94 & 25.94 & 25.94 & 25.94 \\
\hline $\begin{array}{l}\text { Mix } \\
\text { Proportions }\end{array}$ & 0.50 & 0.50 & 0.50 & 0.50 & 0.50 & 0.50 \\
\hline Water & 1.00 & 1.00 & 1.00 & 1.00 & 1.00 & 1.00 \\
\hline Cement & 0 & 0.014 & 0.029 & 0.036 & 0.044 & 0.735 \\
\hline $\begin{array}{l}\text { Plastic pet } \\
\text { bottle Fiber }\end{array}$ & 1.47 & 1.46 & 1.44 & 1.43 & 1.425 & 1.40 \\
\hline Sand & 2.92 & 2.92 & 2.92 & 2.92 & 2.92 & 2.92 \\
\hline $\begin{array}{l}\text { Coarse } \\
\text { Aggregates }\end{array}$ & & & & & & \\
\hline
\end{tabular}

\section{EXPERIMENTAL RESULTS AND DISCUSSION}

The parameters such as Workability, Bulk Density, Compressive Strength and Flexural Strength are discussed and Comparison between the Control Concrete and Plastic Pet Bottle added concrete is represented as follows:

\subsection{Bulk Density/ Unit weight of the Mixes}

The average bulk density or unit weight for all the concrete mixes containing different proportion of plastic pet bottle fiber was determined after 28 days of curing as shown in Table 5 .

Table 5: Average Bulk Density/Unit Weight Results

\begin{tabular}{|c|c|c|c|c|c|c|}
\hline 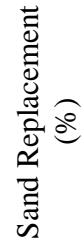 & $\begin{array}{l}z \\
\dot{s}\end{array}$ & 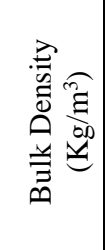 & 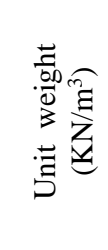 & 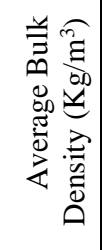 & 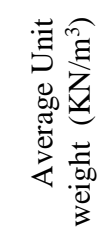 & 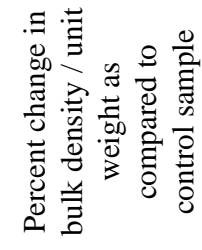 \\
\hline \multirow{2}{*}{0} & 1 & 2490 & 24.90 & \multirow{2}{*}{2475} & \multirow{2}{*}{24.75} & \multirow{2}{*}{0} \\
\hline & 2 & 2460 & 24.60 & & & \\
\hline \multirow{2}{*}{1} & 1 & 2475 & 24.75 & \multirow{2}{*}{2462} & \multirow{2}{*}{24.62} & \multirow{2}{*}{$-0.53 \%$} \\
\hline & 2 & 2450 & 24.50 & & & \\
\hline \multirow{2}{*}{2} & 1 & 2440 & 24.40 & \multirow{2}{*}{2450} & \multirow{2}{*}{24.50} & \multirow{2}{*}{$-0.93 \%$} \\
\hline & 2 & 2460 & 24.60 & & & \\
\hline \multirow{2}{*}{2.5} & 1 & 2420 & 24.20 & \multirow{2}{*}{2434} & \multirow{2}{*}{24.34} & \multirow{2}{*}{$-1.65 \%$} \\
\hline & 2 & 2447 & 24.47 & & & \\
\hline \multirow{2}{*}{3} & 1 & 2430 & 24.30 & \multirow{2}{*}{2415} & \multirow{2}{*}{24.15} & \multirow{2}{*}{$-2.42 \%$} \\
\hline & 2 & 2400 & 24.00 & & & \\
\hline \multirow{2}{*}{5} & 1 & 2350 & 23.50 & \multirow{2}{*}{2375} & \multirow{2}{*}{23.75} & \multirow{2}{*}{$-4.04 \%$} \\
\hline & 2 & 2400 & 24.00 & & & \\
\hline
\end{tabular}

From the results obtained of Bulk Density on replacement of sand by Plastic Pet Bottle Fiber at different amounts concluded that the concrete such produced with increasing value of plastic pet bottle fiber results a concrete lighter weight in comparison to control sample.

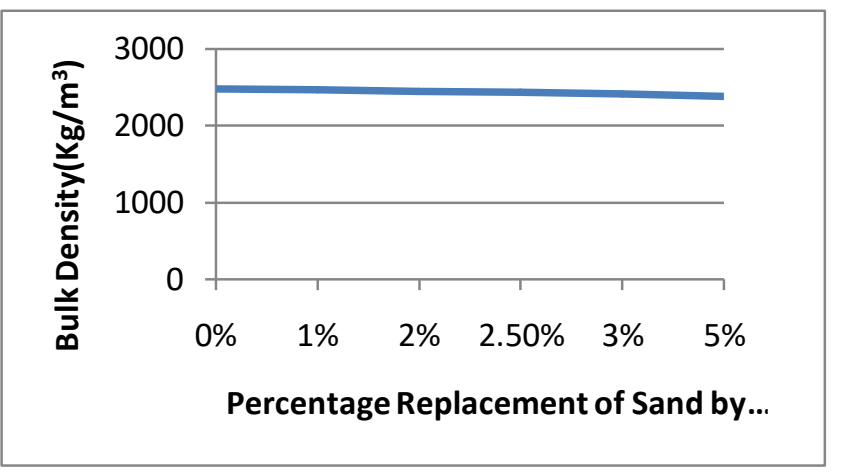

Figure 3: Variation of bulk density of Concrete containing different percentage of Plastic Pet Bottle Fiber.

\subsection{Compressive strength test}

It is the most common of all tests on hardened concrete; in addition, compressive strength is the most important parameter in structural design. Four standard cubes of 150x150x150 mm are formed for each mix. The compressive strength test is carried out according to the BS EN 12390-3 (2002) at ages of 7 and 28 days.

$\mathrm{F}_{\mathrm{cu}}=\mathrm{P} / \mathrm{A}$ 
Table 7: Variation of 7-day compressive strength

\begin{tabular}{|c|c|c|c|c|c|}
\hline $\mathrm{S} \mathrm{N}$ & $\begin{array}{l}\text { Percentage } \\
\text { addition of } \\
\text { plastic pet } \\
\text { bottle Fiber }\end{array}$ & $\begin{array}{l}\text { Failure } \\
\text { load } \\
(\mathrm{KN})\end{array}$ & $\begin{array}{l}\text { Average } \\
\text { Failure } \\
\text { Load } \\
(\mathrm{KN})\end{array}$ & $\begin{array}{l}\text { The } \\
\text { Average } \\
\text { compressive } \\
\text { strength of } \\
\text { seven days } \\
\text { (Mpa) }\end{array}$ & $\begin{array}{l}\text { Percentag } \\
\text { e change } \\
\text { in } \\
\text { compressi } \\
\quad \text { ve } \\
\text { strength }\end{array}$ \\
\hline 1 & \multirow{2}{*}{$0 \%$} & 320 & \multirow{2}{*}{330} & \multirow{2}{*}{14.67} & \multirow{2}{*}{0} \\
\hline 2 & & 340 & & & \\
\hline 3 & \multirow{2}{*}{$1 \%$} & 380 & \multirow{2}{*}{370} & \multirow{2}{*}{16.44} & \multirow{2}{*}{$12.06 \%$} \\
\hline 4 & & 360 & & & \\
\hline 5 & \multirow{2}{*}{$2 \%$} & 395 & \multirow{2}{*}{390} & \multirow{2}{*}{17.33} & \multirow{2}{*}{$18.13 \%$} \\
\hline 6 & & 385 & & & \\
\hline 7 & \multirow{2}{*}{$2.50 \%$} & 370 & \multirow{2}{*}{365} & \multirow{2}{*}{16.22} & \multirow{2}{*}{$10.56 \%$} \\
\hline 8 & & 360 & & & \\
\hline 9 & \multirow[t]{2}{*}{$3 \%$} & 330 & \multirow[t]{2}{*}{320} & \multirow[t]{2}{*}{14.22} & \multirow[t]{2}{*}{-3.07} \\
\hline 10 & & 310 & & & \\
\hline 11 & \multirow{2}{*}{$5 \%$} & 270 & \multirow{2}{*}{280} & \multirow{2}{*}{12.44} & \multirow{2}{*}{-15.2} \\
\hline 12 & & 290 & & & \\
\hline
\end{tabular}

Table 8: Variation of 28-day compressive strength

\begin{tabular}{|c|c|c|c|c|c|}
\hline $\begin{array}{l}\mathrm{S} \\
\mathrm{N}\end{array}$ & $\begin{array}{l}\text { Perc } \\
\text { enta } \\
\text { ge } \\
\text { addi } \\
\text { tion } \\
\text { of } \\
\text { fibe }\end{array}$ & $\begin{array}{l}\text { Failu } \\
\text { re } \\
\text { load } \\
(\mathrm{KN})\end{array}$ & $\begin{array}{l}\text { Averag } \\
\text { e } \\
\text { Failure } \\
\text { load } \\
(\mathrm{KN})\end{array}$ & $\begin{array}{l}\text { Compressive } \\
\text { strength of } \\
28 \text { days } \\
\text { (Mpa) }\end{array}$ & $\begin{array}{l}\text { Percentage } \\
\text { change in } \\
\text { Compressive } \\
\text { strength as } \\
\text { compared to } \\
\text { control sample } \\
(\%)\end{array}$ \\
\hline \multirow[b]{2}{*}{1} & \multirow[b]{2}{*}{$0 \%$} & 560 & \multirow[b]{2}{*}{570} & \multirow[b]{2}{*}{25.33} & \multirow[b]{2}{*}{0.00} \\
\hline & & 580 & & & \\
\hline \multirow[b]{2}{*}{2} & \multirow[b]{2}{*}{$1 \%$} & 630 & \multirow[b]{2}{*}{635} & \multirow[b]{2}{*}{28.22} & \multirow[b]{2}{*}{$11.49 \%$} \\
\hline & & 640 & & & \\
\hline \multirow[b]{2}{*}{3} & \multirow[b]{2}{*}{$2 \%$} & 660 & \multirow[b]{2}{*}{655} & \multirow[b]{2}{*}{29.11} & \multirow[b]{2}{*}{$14.92 \%$} \\
\hline & & 650 & & & \\
\hline \multirow{2}{*}{4} & \multirow{2}{*}{$\begin{array}{l}2.5 \\
\%\end{array}$} & 620 & \multirow{2}{*}{625} & \multirow{2}{*}{27.78} & \multirow{2}{*}{$9.67 \%$} \\
\hline & & 630 & & & \\
\hline \multirow[b]{2}{*}{5} & \multirow[b]{2}{*}{$3 \%$} & 520 & \multirow[b]{2}{*}{530} & \multirow[b]{2}{*}{23.56} & \multirow[b]{2}{*}{$-6.98 \%$} \\
\hline & & 540 & & & \\
\hline \multirow[b]{2}{*}{6} & \multirow[b]{2}{*}{$5 \%$} & 480 & \multirow[b]{2}{*}{485} & \multirow{2}{*}{21.55} & \multirow{2}{*}{$-14.92 \%$} \\
\hline & & 490 & & & \\
\hline
\end{tabular}

7 Day Compressive Test

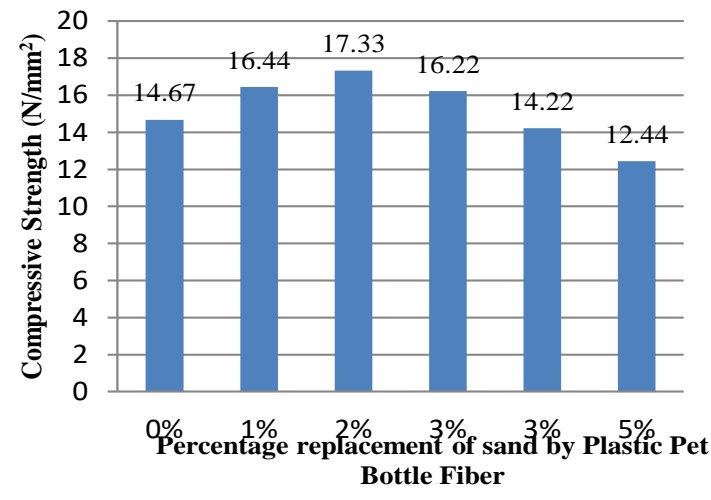

Fig. 6: 7 day compressive strength v/s percentage replacement of sand by Plastic pet bottle fiber

It was noticed that the compressive strength increases with increase in the percentage of plastic pet bottle fiber in 7 day up to $2 \%$ replacement of the sand and then decrease for $2.5 \%$, $3 \%$ and $5 \%$. This may be because when Plastic pet fiber is added to partial replacement of sand, the silica content reduces and equivalent carbon content replaces it. The $\mathrm{Si}-\mathrm{Si}$ bond is weaker than $\mathrm{C}-\mathrm{C}$ is simply that because the $\mathrm{Si}$ atom is bigger than the $\mathrm{C}$ atom the electrons forming the bond are farther from the nuclei and don't lower their energy as much by forming the bond but if plastic pet fiber is added beyond $2 \%$ the compressive strength decreases because all free carbon is bonded or the increase in fiber content decreases bond strength between fibers. Hence replacement of fine aggregate with $2 \%$ replacement will be optimum.
28 Day Compressive Strength

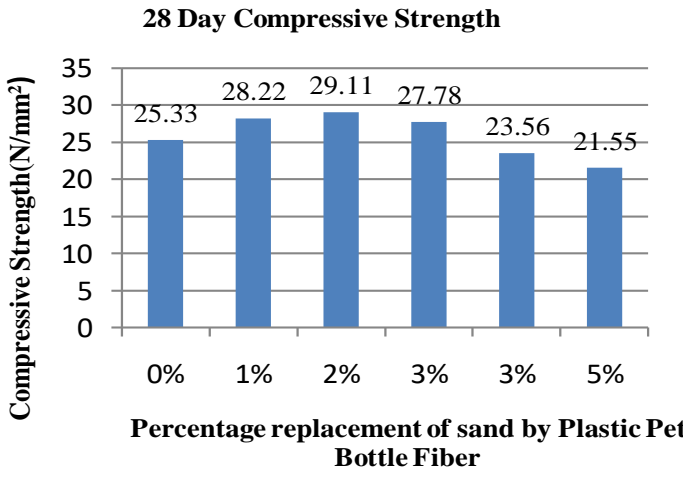

Figure 7: 28 day compressive strength v/s percentage replacement of sand by Plastic Pet Bottle Fiber.

The compressive strength of concrete increases with increase in the percentage of plastic pet bottle fiber in 28 day tests up to $2 \%$ replacement of the fine aggregate with plastic pet bottle fiber and then decrease for $2.5 \%, 3 \%$ and $5 \%$ replacements.

\subsection{Flexural Strength (modulus of rupture) Test}

Flexural strength, also known as modulus of rupture, identified as a material's ability to resist deformation under load. The transverse bending test is most frequently employed, in which a specimen having a rectangular cross-section is bent until fracture using a three-point flexural test technique. The flexural strength represents the highest stress experienced within the material at its moment of rupture. It is measured in terms of stress. The test method for conducting the test usually involves a specified test fixture on a universal testing machine. The value of modulus of rupture depends upon the dimensions of beam and manner of loading. The beam of $300 \times 75 \times 75 \mathrm{~mm}$ size is used in this test to computing modulus of rupture of concrete. 
Table 9: Results of flexural strength test at 7 day

\begin{tabular}{|c|c|c|c|c|c|}
\hline $\begin{array}{l}\mathrm{S} \\
\mathrm{N}\end{array}$ & $\begin{array}{l}\% \\
\text { PET } \\
\text { Adde } \\
d\end{array}$ & $\begin{array}{l}\text { Breaki } \\
\text { ng } \\
\text { Load } \\
(\mathrm{N})\end{array}$ & $\begin{array}{l}\text { Average } \\
\text { Breaking } \\
\text { Load (N) }\end{array}$ & $\begin{array}{l}\text { Flexural } \\
\text { Strength } \\
\left(\mathrm{N} / \mathrm{mm}^{2}\right)\end{array}$ & $\begin{array}{l}\text { Percentage } \\
\text { Change in } \\
\text { Flexural } \\
\text { strength as } \\
\text { compared to } \\
\text { control sample }\end{array}$ \\
\hline \multirow{2}{*}{1} & \multirow{2}{*}{$0 \%$} & 2000 & \multirow{2}{*}{2025} & \multirow{2}{*}{1.44} & \multirow{2}{*}{0} \\
\hline & & 2050 & & & \\
\hline \multirow{2}{*}{2} & \multirow{2}{*}{$1 \%$} & 2150 & \multirow{2}{*}{2175} & \multirow{2}{*}{1.55} & \multirow{2}{*}{$7.63 \%$} \\
\hline & & 2200 & & & \\
\hline \multirow[b]{2}{*}{3} & \multirow[b]{2}{*}{$2 \%$} & 2300 & \multirow[b]{2}{*}{2310} & \multirow[b]{2}{*}{1.64} & \multirow[b]{2}{*}{$13.89 \%$} \\
\hline & & 2320 & & & \\
\hline \multirow{2}{*}{4} & \multirow{2}{*}{$2.5 \%$} & 2450 & \multirow{2}{*}{2435} & \multirow{2}{*}{1.73} & \multirow{2}{*}{$20.13 \%$} \\
\hline & & 2420 & & & \\
\hline \multirow[b]{2}{*}{5} & \multirow{2}{*}{$3 \%$} & 2400 & \multirow{2}{*}{2390} & \multirow{2}{*}{1.70} & \multirow{2}{*}{$18.05 \%$} \\
\hline & & 2380 & & & \\
\hline \multirow{2}{*}{6} & \multirow{2}{*}{$5 \%$} & 2300 & \multirow{2}{*}{2325} & \multirow{2}{*}{1.65} & \multirow{2}{*}{$14.58 \%$} \\
\hline & & 2350 & & & \\
\hline
\end{tabular}

Table 9 indicates the test results of flexural strength (modulus of rupture): Modulus of rupture is calculated using equation: $\mathrm{F}=\mathrm{PL} / \mathrm{BD}^{2}$

\section{VARIATION OF FLEXURAL STRENGTH} OF CONCRETE AT 7 DAY

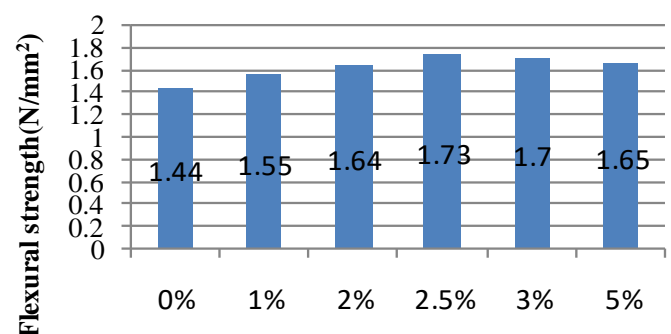

percentage replacement of sand by plastic pet bottle fiber

Figure 9: Variation of Flexural strength of concrete at 7 day

Table 10: Results of flexural strength test at 28 day

\begin{tabular}{|c|c|c|c|c|c|}
\hline $\mathrm{SN}$ & $\begin{array}{l}\text { \%PET } \\
\text { Added }\end{array}$ & $\begin{array}{l}\text { Breaki } \\
\text { ng } \\
\text { Load } \\
(\mathrm{N})\end{array}$ & $\begin{array}{l}\text { Averag } \\
\text { e } \\
\text { Breakin } \\
\text { g Load } \\
(\mathrm{N})\end{array}$ & $\begin{array}{l}\text { Flexural } \\
\text { Strength } \\
\left(\mathrm{N} / \mathrm{mm}^{2}\right)\end{array}$ & $\begin{array}{l}\text { Percentage } \\
\text { change in } \\
\text { Flexural } \\
\text { strength as } \\
\text { compared to } \\
\text { control sample }\end{array}$ \\
\hline \multirow{2}{*}{1} & \multirow{2}{*}{$0 \%$} & 4500 & \multirow{2}{*}{4575} & \multirow{2}{*}{3.25} & \multirow{2}{*}{0} \\
\hline & & 4650 & & & \\
\hline \multirow{2}{*}{2} & \multirow{2}{*}{$1 \%$} & 5000 & \multirow{2}{*}{5100} & \multirow{2}{*}{3.62} & \multirow{2}{*}{$11.38 \%$} \\
\hline & & 5200 & & & \\
\hline \multirow{2}{*}{3} & \multirow{2}{*}{$2 \%$} & 5500 & \multirow{2}{*}{5475} & \multirow{2}{*}{3.89} & \multirow{2}{*}{$19.69 \%$} \\
\hline & & 5450 & & & \\
\hline \multirow{2}{*}{4} & \multirow{2}{*}{$2.5 \%$} & 5600 & \multirow{2}{*}{5700} & \multirow{2}{*}{4.05} & \multirow{2}{*}{$24.61 \%$} \\
\hline & & 5800 & & & \\
\hline \multirow[b]{2}{*}{5} & \multirow{2}{*}{$3 \%$} & 5500 & \multirow{2}{*}{5550} & \multirow{2}{*}{3.95} & \multirow{2}{*}{$21.54 \%$} \\
\hline & & 5600 & & & \\
\hline \multirow{2}{*}{6} & \multirow{2}{*}{$5 \%$} & 5300 & \multirow{2}{*}{5350} & \multirow{2}{*}{3.80} & \multirow{2}{*}{$16.92 \%$} \\
\hline & & 5400 & & & \\
\hline
\end{tabular}

\section{VARIATION OF FLEXURAL STRENGTH OF CONCRETE AT 28 DAY}

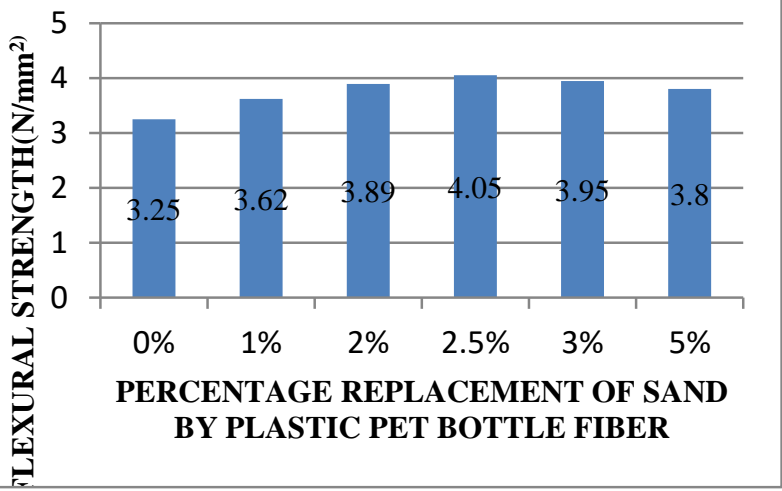

Figure 10 Variation of Flexural strength of concrete at 28 day

\section{CONCLUSION}

1) The inclusion of fibers content increases the flow properties of concrete. The density was also affected but made concrete slightly lighter weight.

2) The maximum compressive strength was at $2 \%$ of fiber content was $14.92 \%$, more over control concrete. Also the maximum flexural strength was at $2.5 \%$ of fiber content were $24.61 \%$ more than control concrete. The optimum strength was observed between 2 to $2.5 \%$ of fiber content for all types of strengths.

3) The concrete with Plastic pet bottle fiber reduces the weight of concrete and thus mortar with plastic fiber can be made into lightweight concrete based on unit weight.

4) The concrete with Plastic pet bottle fiber reduces the weight of concrete and thus mortar with plastic fiber can be made into lightweight concrete based on unit weight.

5) Other kinds of admixtures can be used for the improvement of strength in concrete at further addition of plastic pet bottles fiber.

\section{RECOMMENDATION}

The significant improvements in strengths were observed with the inclusion of plastic pet fibers in concrete. The optimum strength was observed between 2 to $2.5 \%$ of fiber content for all types of strengths, thereafter reductions in strength were observed. Hench for the optimum strength $2-2.5 \%$ of the plastic pet bottle fibers can be recommended to use in concrete production as a replacement of sand. And also from this experimental study, the PET bottles fiber would appear to be low-cost materials which would help to resolve solid waste problems and preventing environmental pollution. And for the further research more percentage of the plastic pet bottle fiber can be added with the use of super plasticizers -admixtures if required to meet the target strength of the concrete. And also the plastic pet bottle can be grinding and replacing of coarse aggregate partially can also be studied for the further application in concrete as well in future. 


\section{REFERENCE}

[1]Arivalagan S. et al 5(11): "Experimental investigation on partial replacement of waste plastic in concrete" volume: 3 ISSN: 2277-9655.

[2]Bandodkar et al. (2011) "Pulverised PET Bottles as Partial Replacement for Sand" International Journal of Earth Sciences and Engineering ISSN 0974-5904, Volume 04, No 06 SPL, October 2011, pp. $1009-1012$

[3]Bureau of Indian Standards, New Delhi. IS 2386-3 (1963). Methods of Testing for Aggregates for Concrete, Part III: Specific gravity, density, voids, absorption and bulking

[4]Bureau of Indian Standards, New Delhi. IS 2386-5 (1963). Methods of Testing for Aggregates for Concrete, Part V: Soundness.

[5]Bureau of Indian Standards, New Delhi. IS 2386-1 (1963). Methods of Testing for Aggregates for Concrete, Part I: Particle Size and Shape.

[6]Bureau of Indian Standards, New Delhi. IS 10262 (2009). Guidelines for concrete mix design Proportioning.

[7]Bureau of Indian Standards, New Delhi. IS 456 (2000). Code of practice for Plain and Reinforced Concrete (fourth Revision).

[8]Bureau of Indian Standards, New Delhi. IS 7320 (1974). Specification for Concrete Slump test Apparatus.

[9]Bureau of Indian Standards, New Delhi. IS 516 (1959). Methods of Tests for Strengthof Concrete.

[10] Frigione M. (2010). Recycling of PET bottles as fine aggregate in concrete. Waste Management, 30, 1101-1106.

[11] IS: 383-1970, "Specification for coarse and fine aggregate ", Bureau of Indian Standards, New Delhi, 1970

[12] Verma S, Arora S. Replacement of Natural Sand in Concrete by Polyethylene Bottles. International Research Journal of Engineering and Technology (IRJET). 2015; 2(1):1-5.

Sudip Joshi is a civil engineer. He is studying his M.Sc. degree in Technology and innovation management from Institute of Engineering Pulchowk campus Tribhuvan University, Nepal. And his Bachelor's of engineering degree in Civil Engineering from Tribhuvan University, Nepal. Currently, he is working as Project manager in Himalayan Builders and Engineer Pvt. Ltd. Kathmandu Nepal. His areas of interests in research are efficient Civil engineering construction \& materials and low cost buildings.

Nawraj Bhattarai, (Department of Mechanical Engineering, Tribhuvan University/ Pulchowk Campus/ Pulchowk, Lalitpur Nepal) 